Article

\title{
Suburban Fertility and Metropolitan Cycles: Insights from European Cities
}

\author{
Jesús Rodrigo-Comino ${ }^{1,2} \mathbb{D}$, Gianluca Egidi ${ }^{3}$, Adele Sateriano ${ }^{4, *}$, Stefano Poponi ${ }^{5}$, Enrico Maria Mosconi ${ }^{6}(\mathbb{D}$ \\ and Antonio Gimenez Morera ${ }^{7}$
}

check for

updates

Citation: Rodrigo-Comino, J.; Egidi, G.; Sateriano, A.; Poponi, S.; Mosconi, E.M.; Gimenez Morera, A. Suburban Fertility and Metropolitan Cycles: Insights from European Cities. Sustainability 2021, 13, 2181. https:// doi.org/10.3390/su13042181

Received: 18 January 2021

Accepted: 15 February 2021

Published: 18 February 2021

Publisher's Note: MDPI stays neutral with regard to jurisdictional claims in published maps and institutional affiliations.

Copyright: (c) 2021 by the authors. Licensee MDPI, Basel, Switzerland. This article is an open access article distributed under the terms and conditions of the Creative Commons Attribution (CC BY) license (https:// creativecommons.org/licenses/by/ $4.0 /)$.
1 Department of Geography, University of Valencia, 46010 Valencia, Spain; jesus.rodrigo@uv.es

2 Department of Physical Geography, Trier University, 54296 Trier, Germany

3 Department of Agricultural and Forestry Sciences (DAFNE), Tuscia University, 01100 Viterbo, Italy; egidi.gianluca@unitus.it

4 Independent Researcher, 00154 Rome, Italy

Faculty of Economics, Niccolò Cusano University, 00166 Rome, Italy; stefano.poponi@unicusano.it

6 Department of Economics, Engineering, Society and Business, University of Tuscia, 01100 Viterbo, Italy; enrico.mosconi@unitus.it

7 Departamento de Economia y Ciencias Sociales, Universitat Politècnica de València, 46022 Valencia, Spain; angimo1@doctor.upv.es

* Correspondence: adele.sateriano.pul@gmail.com; Tel.: +39-6-61571036; Fax: +39-6-615710

\begin{abstract}
Being largely diversified along the urban-rural gradient, fertility gaps have demonstrated to fuel metropolitan expansion, contributing to natural population growth and social change. In this direction, population dynamics and economic transformations have continuously shaped urban cycles in Europe. Assuming suburban fertility to be a relevant engine of metropolitan growth, the present study investigates and discusses the intrinsic relationship between fertility transitions and urban expansion, focusing on European metropolitan regions. An average crude birth rate referring to the last decade (2013-2018) was estimated from official statistics at 671 Functional Urban Areas (FUAs, Eurostat Urban Audit definition) of 30 European countries, distinguishing 'central cities' from 'suburban' locations. Local contexts with a higher crude birth rate as compared with neighboring settlements were identified analyzing differential fertility levels in urban and suburban locations. By providing an indirect, comparative verification of the 'suburban fertility hypothesis' in European cities, the results of this study demonstrate how suburbanization has been basically associated to younger and larger families-and thus higher fertility levels-only in Eastern and Southern Europe. Birth rates that were higher in suburbs than in central cities were observed in $70 \%$ of Eastern European cities and 55\% of Mediterranean cities. The reverse pattern was observed in Western (20\%), Northern (25\%) and Central (30\%) Europe, suggesting that urban cycles in the European continent are not completely phased: most of Western, Central, and Northern European cities are experiencing re-urbanization after a long suburbanization wave. Demographic indicators are demonstrated to comprehensively delineate settlement patterns and socioeconomic trends along urban-suburban-rural gradients, giving insights on the differential metropolitan cycles between (and within) countries.
\end{abstract}

Keywords: birth rates; demographic transition; suburbanization; Urban Audit; European regions

\section{Introduction}

Socioeconomic transformations and population dynamics have influenced the intrinsic development of European countries and regions [1-6]. Intense demographic changesusually reflecting the 'first demographic transition' [7]-have occurred since the 18th century, moving from high to low fertility and from shorter to longer life expectancy [8-15]. Paralleling urbanization and population concentration in central cities, these changes were mostly observed between the early 1950s and the late 1980s in advanced countries [16]. 
In recent decades, more subtle and less characteristic population changes have been identified, the so-called 'Second Demographic Transition'. This process was responsible for social transformations-associated with moderate demographic dynamics-and a more subtle population redistribution over larger metropolitan regions [17]. This transition has reflected changes in individual behaviors and socio-demographic characteristics of households $[7,15,18]$, leading to population ageing and a greater heterogeneity in the demographic patterns over both time and space $[5,9,19]$. Being increasingly sensitive to economic downturns [13,20-23], population dynamics have been more extensively investigated with the second demographic transition [1]. In this period, a rapid transformation of gender roles, especially for women $[15,17,24]$, emerged as far as job market engagement $[25,26]$ and educational achievement $[27,28]$ are concerned, delineating new fertility behaviors [1]. At the same time, a greater spatial variability in the population growth rates has been observed, especially in most advanced economies $[8,29,30]$.

Assuming population trends as related with socioeconomic forces [31-33], regional patterns underlying sequential demographic transitions were demonstrated to reflect societal changes oriented along urban-rural gradients [34-37]. As a result of the first demographic transition, fertility divides across space were associated with background socioeconomic conditions [20,38-41]. In this context, fertility was found to be higher in rural districts and lower in central cities in the United States [42], Eastern Europe [43-47], Northern Europe [2,48], England and Wales [49,50], the Netherlands [50,51], Italy [52], Germany, and Austria $[38,47]$. These divides rose likely more rapidly than temporal differences in birth rates [53-56]. Especially in European countries [57-60], polycentric regional structures and socially cohesive local communities have leveraged new relationships between central cities, suburbs, and the surrounding rural areas [61-64]. As a matter of fact, in addition to regional fertility divides that are typical of the first demographic transition, fertility differences across urban, suburban, and rural settlements may indicate important social constraints, especially with the second demographic transition [37]. Within metropolitan regions, suburbs concentrated the highest birth rates [2], with single-family householdsthe dominant family type in suburbs-directly related to higher fertility levels [56]. An in-depth investigation of neighborhood's characteristics suggests that contextual effects are intrinsically associated with fertility choices [65-67]. The overall costs of childbearing also varied among urban, suburban, and rural locations [68-71]. At the same time, population growth (and the consequent fertility rise) in suburban areas is a consequence of increased in-migration $[4,17,31,44,54,72-74]$.

Based on these considerations, this study provides a comparative investigation of the relationship between demographic transitions and urban cycles, with a specific focus on suburbanization, verifying whether different types of metropolitan expansion were associated with specific fertility trends [75-77]. Although several socioeconomic forces were demonstrated to contribute to higher suburban fertility [23,56,78-80], the intimate linkage between urban cycles and suburban fertility was still underexplored in Europe [81-83]. Our contribution assumes suburban fertility increasing over time with respect to both urban and rural fertility (in line with predictions of the so-called 'suburban fertility hypothesis' [84-86]). An in-depth analysis of a time series of gross birth rates that were derived from official statistics and covering the last decade was run at the metropolitan scale over the European continent, distinguishing local fertility levels in 671 Functional Urban Areas (FUAs) from 30 countries classified in eight macro-regions, distinguishing central cities from suburban areas. This comparative analysis sheds light on the different timing of urban cycles across cities, evidencing the spatial unbalance of metropolitan fertility patterns across east-west and north-south gradients in Europe. These dynamics are interpreted as a result of distinctive development paths and the legacy of past trajectories of urban and regional growth. Understanding local fertility patterns and, more generally, spatial trends in the natural growth rate of urban populations (i.e., the natural population balance derived from births and deaths at a given time interval) may contribute to a better knowledge of background (socioeconomic) contexts that guarantee the conditions for sus- 
tainable development of cities and metropolitan regions. With economic crisis affecting some countries in Europe and re-orienting migration flows-the most effective engine of urban growth-to other, more attractive destinations in and outside Europe, fertility rates (directly contributing to the natural population growth) once again becomes an important factor in the sustainable and balanced development of urban societies, allowing for a greater resistance to exogenous economic shocks.

\section{Methodology}

Based on maps and descriptive statistics, our study illustrates an empirical analysis of the spatial distribution of a crude birth rate that is derived from official statistics disseminated by the Urban Audit (UA) program (Eurostat; https: / /ec.europa.eu/eurostat (accessed on 13 December 2020)) over central cities and suburbs in Europe. UA program identified the physical boundaries of a number of cities and urban areas in Europe, when considering a sufficiently large area (the so-called Functional Urban Area, FUA) defined on the base of commuting flows that are derived from population census. According to the UA framework, urban areas were regarded as homogeneous 'travel-to-work' areas, maximizing the internal flows of commuters and minimizing commuting flows to surrounding (nonmetropolitan) areas. Within the UA nomenclature, the Functional Urban Area consists of a 'city' and its 'commuting zone' (https: / / ec.europa.eu/eurostat/web/cities/spatial-units (accessed on 13 December 2020)). Following the UA definition, "a city is a Local Administrative Unit (LAU) where the majority of the population lives in an urban center of at least 50,000 inhabitants". In other words, this spatial unit was defined as the inner municipality of the respective metropolitan area and it was labeled in the present study as the 'central city'. Instead, the 'commuting zone' was regarded as the 'suburban' spatial unit in this study, basically corresponding with the 'Large Urban Zone' (LUZs) of each city. The specific composition of spatial units (municipality level) for each city in Europe was provided in a file that was downloadable from the Eurostat UA web site: https: / / ec.europa.eu/eurostat/documents/345175/501971/EU-28_2012.xlsx (accessed on 13 December 2020).

A total of 671 urban agglomerations in Europe were considered in the present study with a variable sample size by country; the highest number of urban agglomerations, as defined by UA, was located in Germany. We considered all of the agglomerations (i.e., FUAs) with valid and reliable statistical data on fertility available over a defined time frame. The sample covered the whole urban hierarchy in Europe, from the largest cities (London and Paris) to the regional/prefectural head towns and even smaller agglomerations. While the large majority of FUAs totalized a resident population $>100,000$ inhabitants, a relatively small number of FUAs in the sample (5.9\%) had a population (2018) that was slightly lower than 100,000 inhabitants, but always above 50,000 inhabitants. The delineation of city's boundaries, the definition of urban agglomerations (in both functions and morphology), and the determination of a physical threshold (e.g., population size), above which a human settlement can be considered as forming a 'urban center' or a 'city', is certainly a matter of intense research. Every official statistical system in the world was providing the own nomenclature to classify 'urban' and 'rural' areas, depending on the intrinsic characteristics of settlements. Because the European urban hierarchy is the sum of many separate national systems with different characteristics, functions and forms-having heterogeneous genesis and largely variable development over more or less long times (from ancient Greeks and Romans two millennia ago up to nowadays) - it is rather difficult to develop a specific classification that is suitable to catch up the local and regional peculiarities of each national urban system in Europe.

Despite showing intrinsic issues and some limitations, we considered the Urban Audit classification of urban settlements in Europe as one of the best examples in this perspective, in turn providing freely downloadable and fully updated statistical data, variables, and indicators of relevance for demographic research. As in any classification system, the empirical results of any statistical analysis derived from UA city's nomenclature should 
be regarded as fully comparable, conceptually reliable, and statistically robust only when using the same (or similar) nomenclature(s). In this study, we adopted the UA classification instead of other nomenclatures (e.g., derived from non-official statistical sources), because our final aim was to explore the whole range of cities and towns within the European urban hierarchy, from the largest to the smallest, giving aggregate results by country and macro-region, and, thus, delineating general fertility trends over sufficiently larger reference areas.

As a fertility indicator largely used in regional demography, we adopted the average crude birth rate separately computed for the two spatial partitions that were delineated with UA ('central city' and 'suburbs'). Crude birth rate was calculated as the total number of births per 1000 resident inhabitants at each location (671 agglomerations) in 30 European countries (Figure 1). Being one of the most reliable indicators of fertility, this rate traditionally provides a gross assessment of fertility patterns and trends over time in sufficiently large spatial partitions. The rate was computed as the average of the last six years available to official statistics (2013-2018) to minimize temporal volatility, possible lacking data, and uncertainties in the national/regional fertility time series. The average estimations of crude demographic rates over a sufficiently long time interval were demonstrated to be representative of general spatial trends and more stable over time than single-years values [87].

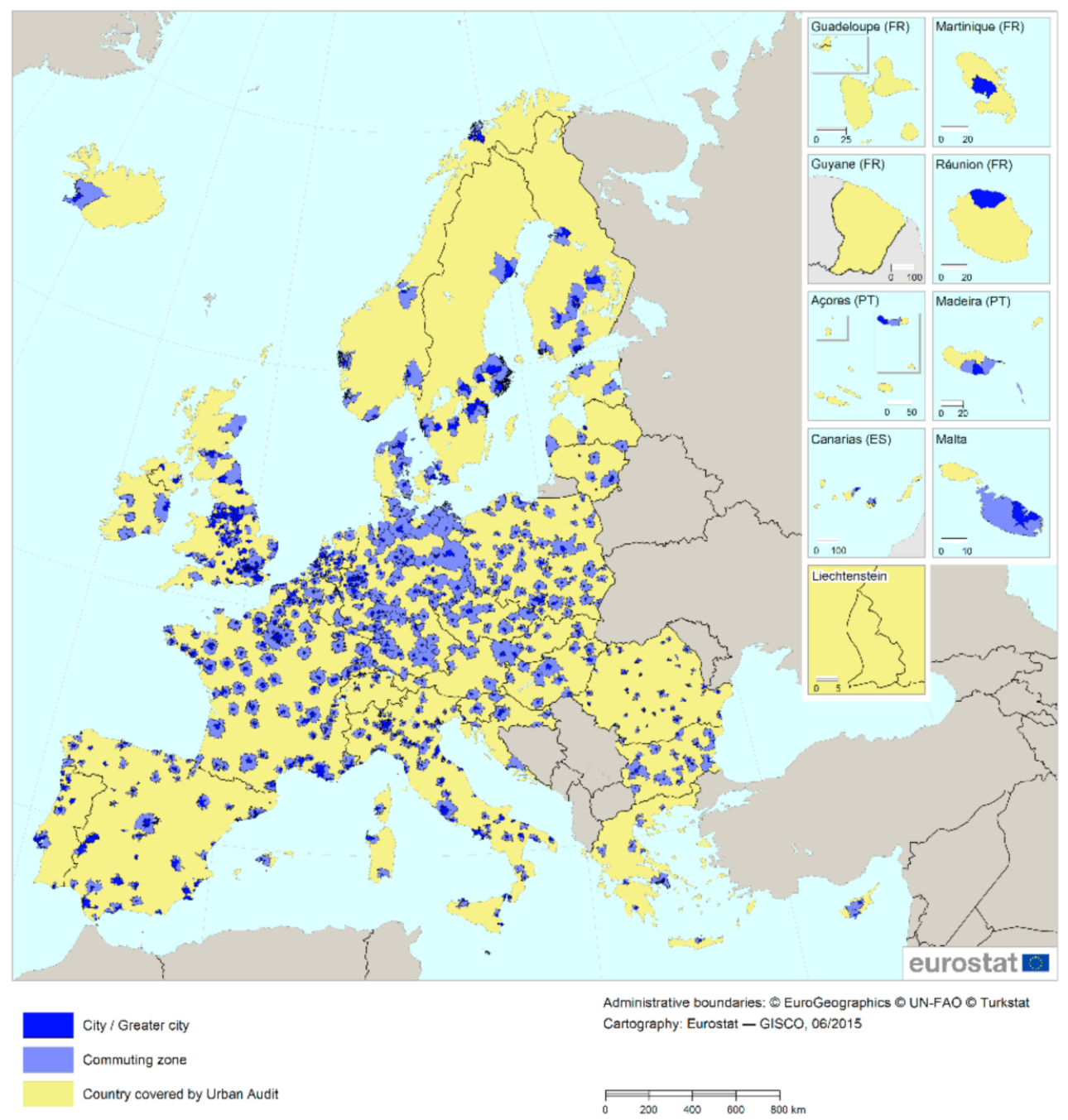

Figure 1. Spatial distribution of metropolitan agglomerations in Europe included in the Urban Audit (Eurostat) sample and distinguishing 'central cities' (dark blue) from 'suburbs' (soft blue). 
An additional indicator was calculated, for each FUA, dividing the average crude birth rate that was observed in 'suburbs' with the rate observed at the 'central city' location. The positive or negative values of this indicator outline a higher birth rates in 'suburbs' or in 'central cities'. The values of this indicator have been subsequently analyzed grouping cities by (i) country and (ii) macro-region in Europe. Eight macro-regions were considered here: Atlantic (United Kingdom, Ireland, the Netherlands), Western (France, Belgium, Luxembourg), Northern (Denmark, Finland, Sweden, Norway), Central (Germany, Austria, Switzerland), North-Eastern (Czech Republic, Estonia, Lithuania, Latvia, Poland, Slovak Republic), Eastern (Bulgaria, Croatia, Romania, Slovenia, Hungary), Southern (Greece, Cyprus, Malta, Italy), and South-Western (Spain and Portugal).

Although macro-regional classifications of countries, in Europe as everywhere in the world, are a subjective matter, a rationale for this classification was provided in an earlier study [88], evaluating the appropriateness of regional classifications for European macro-regions. The simplified division in six macro-regions of Europe provided in that study was considered here, splitting some regions in sub-regions. More specifically, Eastern Europe and Southern Europe in this study were divided into two sub-regions considering, respectively, the North-South geographical gradient in Eastern Europe and the East-West gradient in Mediterranean Europe. Country data were also used in the analysis, so the macro-region was only considered one of the possible spatial units of interest for this study; country data can overcome the (supposed) subjectivity of the macro-regional classification adopted here.

Based on the (per cent) frequency of cities with a higher suburban birth rate by country, the average values of this rate were also calculated for each macro-region. The per cent difference in the crude birth rate between 'suburbs' and 'central cities' was finally computed and reported at the macro-regional scale in order to give a comparative overview of the trends in metropolitan fertility all over Europe. With this perspective in mind, the relationship between the relative proportion (per cent rate) of cities with higher suburban fertility in the total agglomerations and the (per cent) difference in the crude birth rate between suburbs and central cities at each European country was investigated. We run a correlation analysis based on Pearson coefficients testing for significant (pairwise) linear relationships at $p<0.05$ to achieve this objective. After testing for linearity, an ordinary least square regression was run while considering the latter variable as dependent and the former variable as predictor. The best-fit estimation of the linear model was provided together with a classical goodness-of-fit metric (adjusted $\mathrm{R}^{2}$ ). The role of capital cities was finally investigated using a dummy variable discriminating fertility dynamics in this specific sub-sample of cities, while considering the absolute different in crude birth rates at a central city and suburban locations as pivotal analysis' variable.

\section{Results}

\subsection{Differences in Crude Birth Rates at 'Central City' and 'Suburban' Locations}

A marked spatial heterogeneity in crude birth rates at 'central city' and 'suburban' locations has been observed across Europe (Figure 2). Higher birth rates in central cities have been more frequently recorded in the Atlantic, Western, Northern, and Central Europe than elsewhere in the continent. In those contexts, which often correspond with the most advanced economies and societies of the continent (e.g., France, United Kingdom, Germany, and the Netherlands), the fertility divide between 'central cities' and 'suburbs' was moderate to high (higher in 'central cities'). The percentage of cities with higher fertility levels in suburbs increased in the Eastern European region, reaching the maximum values in countries, such as Estonia and Slovenia. 


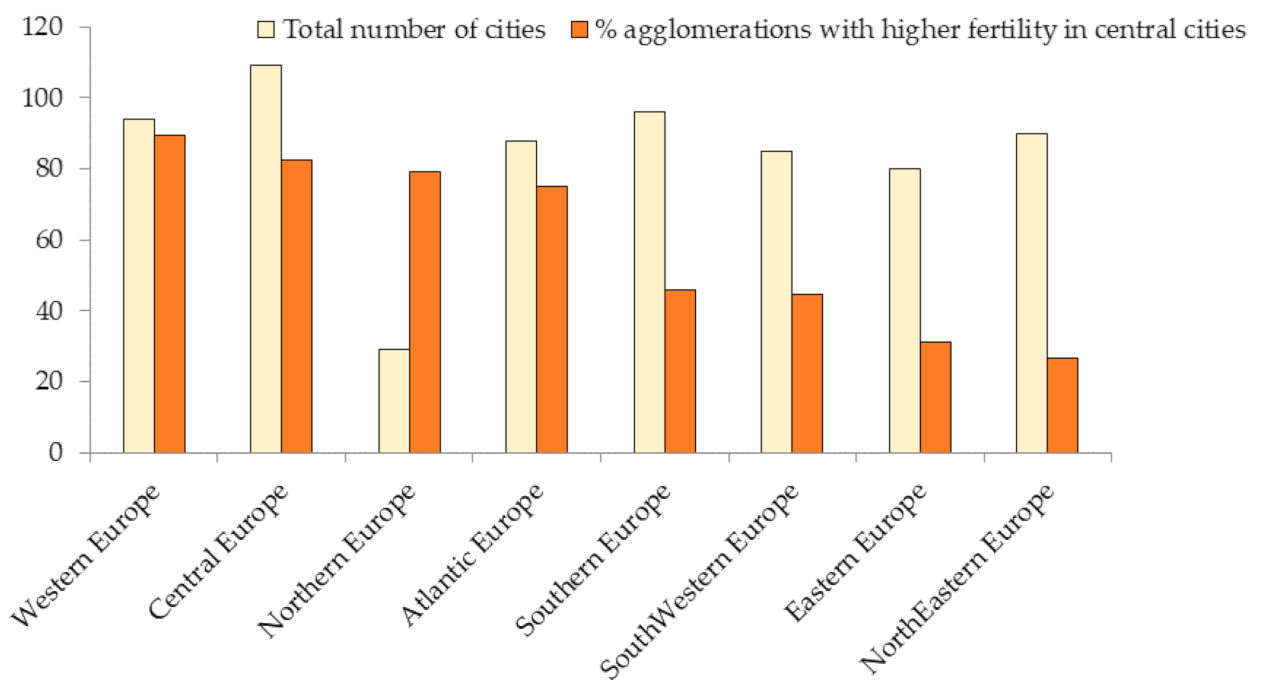

Figure 2. Per cent agglomerations with the higher birth rate in central cities in total agglomerations (left, yellow columns, left scale) and the total number of surveyed cities (right, orange columns) by macro-region in Europe.

Conversely, the Mediterranean countries (both South-Eastern and South-Western Europe) positioned in-between 'Western' and 'Eastern' Europe, displaying particularly mixed results as far as the crude birth rate is concerned. In some cities, fertility was higher in suburban locations; in other cities, fertility was higher in central locations, with no clear spatial patterns discriminating between the two cases. Interestingly, cities in Southern Europe and South-Western Europe showed similar crude birth rates and a mixed urban/suburban fertility, outlining a substantial homogeneity in demographic patterns in the Northern Mediterranean basin. The same findings have been observed when comparing the Eastern and North-Eastern European regions, with cities mostly belonging to the same urban typology (i.e. referring, more or less intensively, to a 'planning model' that is typical of Socialist countries).

\subsection{Suburban Fertility: A Country-Scale Analysis}

The relationship between the proportion of cities with higher suburban fertility and the difference in the crude birth rate between suburbs and central cities was illustrated for each European country (using official abbreviations) in Figure 3. This scatterplot identifies a linear, statistically significant relationship ( $\mathrm{y}=0.19-0.10$, adj- $\mathrm{R}^{2}=0.81, p<0.001$ ) between the two variables, which suggests that, in countries where a higher suburban fertility was observed in a larger number of FUAs, a higher divide between suburban and urban fertility was also recorded, on average. These findings outline how the frequency and intensity of fertility patterns and the underlying processes (in this case, suburban fertility) are linearly and strongly correlated. However, more heterogeneous conditions have been observed in Mediterranean Europe, where cities with significantly higher values of suburban fertility mixed up with cities showing the reverse pattern (higher fertility in central settlements). This demographic pattern can be justified with the assumption that Southern Europe has recently experienced a prolonged suburbanization, with urban settlements transitioning towards more dispersed models. These peri-urban settlements were attracting younger couples with a high propensity for marriage and childbearing, thus leveraging the fertility rates.

A further elaboration focused on the differential fertility of suburbs and central cities in the European capitals (Figure 4). Paralleling the results that are presented above, the crude birth rates were higher in central cities than in suburbs (positive values of the indicator) in the capital cities of Western, Northern, and Central Europe, with the only exception of Lisbon and Vilnius, although the fertility gap between suburbs and 
central cities was rather moderate (less than 0.2 births per 1000 inhabitants) in these two agglomerations. Copenhagen, Bruxelles, Bern, and Oslo showed the highest cityto-suburbs differentials in crude birth rates. Capital cities in Southern Europe (Rome, Madrid, and Athens) displayed higher suburban fertility, while Lefkosia occupied a more mixed position. Eastern European capital cities, on average, showed similar demographic dynamics (suburban fertility higher than urban fertility). Interestingly, Dublin, the capital city of Ireland, showed a fertility pattern that was similar to South-Eastern cities. Despite being classified as an 'Atlantic' country, recent socioeconomic dynamics in Ireland often resembled those that were observed in more peripheral and economically disadvantaged countries of Eastern and Southern Europe. Moreover, the 2007 crisis intensively impacted this country, similarly to what was observed, e.g., in Greece, Spain, Portugal, or Italy.

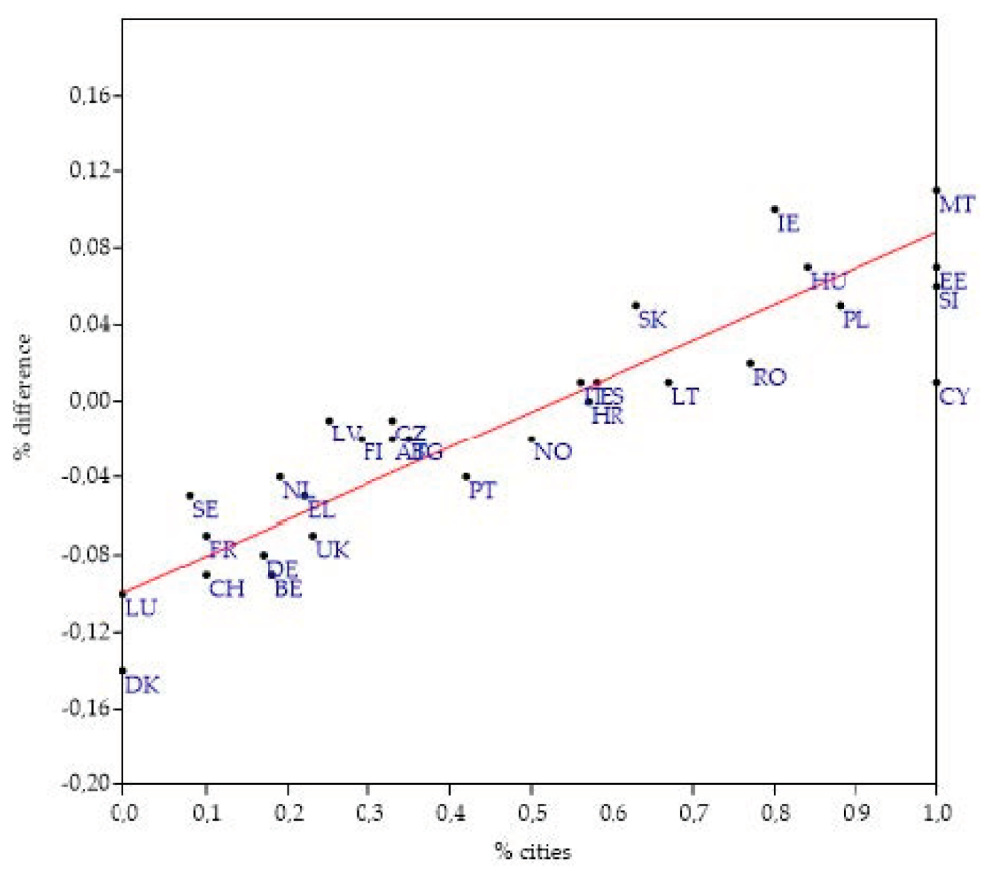

Figure 3. Relationship between the per cent rate of cities with higher suburban fertility in total agglomerations ('\% cities') and the per cent difference in the crude birth rate between suburbs and central cities ('\% difference') at each European country (official abbreviations of countries provided by Eurostat were used).

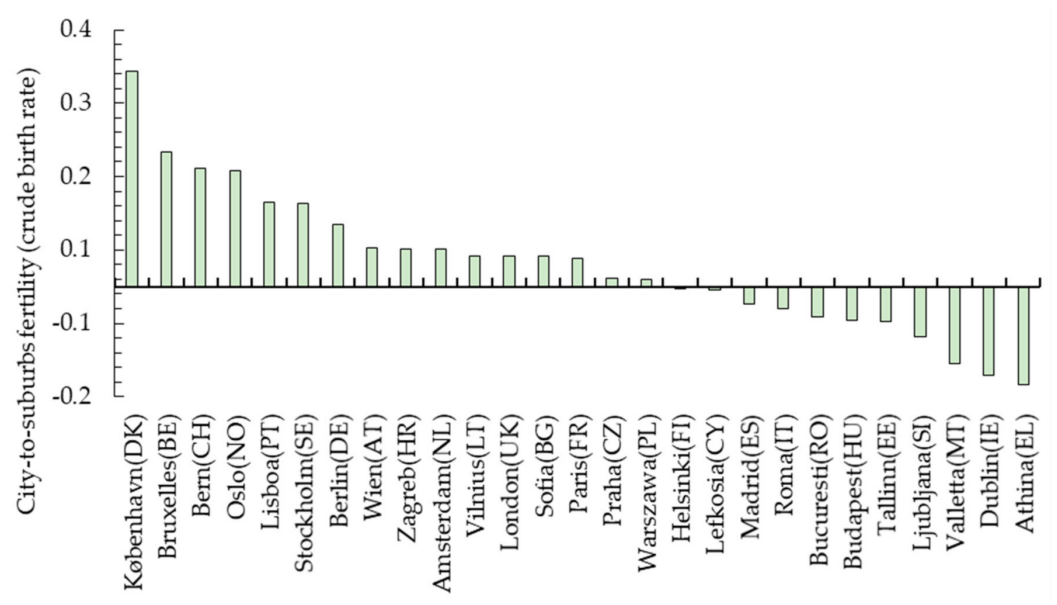

Figure 4. The spatial distribution of the absolute difference in crude birth rates between central cities and suburbs in the European capital cities considered in this study. 


\section{Discussion}

Regional fertility regimes had changed rapidly in Europe resulting from joint socioeconomic transformations [19]. Heterogeneous population dynamics-mainly related to the second demographic transition-have involved new family relationships, resulting in a decreased fertility $[5,18,88]$. These patterns exerted an influential impact on both central cities and suburbs, leading, in some cases, to a re-densification of inner cores. In other cases, urban diversification with moderate population shrinkage was observed [58,89-93]. More recently, recessionary shocks often led to greater spatial complexity in fertility regimes, leveraging structural divides in urban and rural populations [94-97]. For instance, the most recent financial crisis (variably affecting the European countries in the early 2010s) has resulted in important, local-scale consequences of demographic transitions [22,98-102], going beyond the traditional urban-rural divide in crude birth rates.

Our study delineates the intimate relationship between urban cycles and demographic transitions, evidencing how the local fertility levels diversified across metropolitan regions in Europe [103-106]. However, this pattern is far from being homogeneous across European countries. Fertility differentials between central cities and suburbs became more mixed within countries in the same macro-region and within metropolitan regions in the same country. A general trend that emerges from our study suggests how macro-regions are relevant spatial units for providing a differential analysis of gross fertility rates in metropolitan regions, distinguishing central cities from suburbs. In this context, both East-West and North-South geographical gradients seem to have an impact on metropolitan fertility: the birth rates were found to be higher in central cities than in suburbs in many agglomerations belonging to Western, Northern and Central European countries, from Atlantic to Baltic Sea. Cities in Eastern Europe are experiencing the reverse condition, with birth rates being systematically higher in suburbs than in central cities. Thus, the West-East gradient resembles the demographic role of inner cores (higher in Western Europe) and suburbs (higher in Eastern Europe). A similar pattern was observed moving from Northern to Southern Europe. This gradient also highlights the role of inner cores (higher in Northern Europe) and suburbs (higher in Southern Europe). However, agglomerations in Mediterranean Europe positioned in-between Western and Eastern cities as far as the spatial heterogeneity in fertility rates is concerned.

Taken together, these results may reflect, in each individual agglomeration, the dominant phase of the urban life cycle. North-Western agglomerations entered-since years-in a phase of re-urbanization, evolving toward new (and, possibly, more advanced and spatially articulated) forms of urban expansion (e.g., polycentric development). With re-urbanization, the inner cores were progressively re-attracting young population and couples with a high propensity for marriage and childbearing, indirectly contributing to higher (average) birth rates.

Conversely, Eastern European cities are still experiencing a last phase of suburbanization, with intense population growth in peri-urban districts and a substantial stability (or even shrinkage) of inner cores. These districts were mostly industrial and they are now experiencing a difficult conversion to a different production base grounded on advanced services, telecommunications, research and development, financial activities, and real estate- the typical economic structure of inner cities in Western, Central, and Northern Europe. In some ways, Eastern cities are still under the (indirect) legacy of Socialist planning-privileging centralized urban growth and stimulating radio-centric expansion around central cores, forming semi-dense suburbs and perpetrating a mono-centric structure of cities.

Being strongly differentiated from both Western and Eastern agglomerations, Mediterranean cities are, actually, the most heterogeneous socioeconomic context in Europe. In this macro-region, cities undergoing rapid re-urbanization (e.g., in Spain or Portugal) mixed up with cities still in a late suburbanization wave (e.g., in Greece or Southern Italy). However, despite significant differences at the country scale, regional demographic contexts in the Mediterranean are relatively homogeneous as far as the differential fertility in suburbs and 
central cities testifies. For instance, differences in the crude birth rates between suburbs and central cities are negligible between South-Western Europe and Southern Europe, documenting a similar demographic context in Mediterranean Europe, from Portugal to Cyprus. The same evidence was found when comparing Eastern and North-Eastern Europe-from Romania to Estonia. These two macro-regions include countries (more or less strictly) that adhere with the Socialist urbanism model before the 1990s.

In this perspective, it is also worth mentioning that the Second Demographic Transition has involved Eastern Europe and the Northern Mediterranean basin later than the other European countries [6]. The effects of such a recent transition on urban population gave rise to a deceleration of the intense shift from compact cities to polycentric and spatially balanced settlements, typically observed in these macro-regions in the 1980s and the 1990s [64,107,108]. In such contexts, internal and foreign migration both significantly influenced demographic change, likely more intensively than in other European countries [3,109-111]. At the same time, internal migrations from central cities to suburbs and rural contexts ('counter-urbanization') took place, at least in some contexts (e.g., Greece), over the last two decades [112-115]. In both Spain and Portugal, many young families decided to move to peri-urban districts farther away from inner cores. Peri-urban areas in both Madrid and Barcelona provinces were demonstrated to have stable and systematically high fertility levels, with smaller urban centers in the same districts displaying, on average, significantly lower birth rates [75,105,116-119].

In such contexts-both in Eastern Europe and in the Mediterranean basin-young people in marginal European countries have experienced a higher social vulnerability thanks to the inherent increase in 'flexible work arrangements' [120-122], with lower income than in the past $[118,119,123]$. At the same time, suburbanization (mainly in South-Eastern Europe) has sometimes represented a sort of 'lock living' mode-functionally different from the suburbs that are typical of North-Western European cities-while resembling the morphological characteristics of the United States suburban landscapes [124-128]. Therefore, peri-urban landscapes in the Mediterranean and Eastern Europe are increasingly populated with dispersed settlements that are made up of (mostly) detached houses with private gardens and swimming pools [129-132]. This context resulted in a particularly heterogeneous relationship between class segregation, demographic change, and urban growth [133-137].

\section{Conclusions}

The use of demographic indicators will delineate present and future settlement patterns and trends along urban-suburban-rural gradients, giving insights on differential metropolitan cycles across the European continent. With this perspective in mind, the differential levels of fertility in suburbs and inner cities observed across countries and regions in Europe were demonstrated to be indicative of the different timing in metropolitan cycles of European cities, with significant differences still oriented along north-south and east-west gradients. The results of our study indicate how re-urbanization with more intense demographic dynamics in central cities was characteristic of Northern, Western, and Central European countries. Cities in these macro-regions are experiencing a (more or less) intense re-urbanization. Suburbanization processes (resulting in a higher fertility in suburbs) are still dominant in Eastern European cities, which are evolving slowly toward less compact (and more discontinuous) settlement models. Mediterranean cities are positioned in-between Western and Eastern agglomerations, displaying mixed fertility trends that reflect heterogeneous patterns still characteristic of suburbanization in some cities and more evident patterns of re-urbanization in other cities.

These results outline a particularly high spatial heterogeneity in fertility levels across Europe, whose drivers are together social, economic, and territorial. A better knowledge of demographic transitions in different European regions contributes to integrated management of metropolitan areas experiencing different stages of a complete urban cycle, from urbanization to re-urbanization. In these regards, fertility decline and population aging 
are basic issues of metropolitan planning in the coming decades. Further investigations detailing the specific role of population/urban size in shaping the local/regional fertility dynamics are particularly meaningful in this direction of study. Reliable and robust indicators that are derived from official statistics that may assess changes over time in fertility levels at the very local scale are increasingly required to inform spatial planning and development policies oriented toward urban sustainability, social cohesion, and a balanced population within metropolitan regions. Sufficiently long time series of demographic indicators aggregated at municipal and/or economic district scales are needed in such a perspective.

Author Contributions: Conceptualization, A.S. and S.P.; methodology, A.G.M.; software, J.R.-C.; validation, E.M.M., G.E. and S.P.; formal analysis, J.R.-C.; investigation, A.G.M.; resources, S.P.; data curation, E.M.M.; writing—original draft preparation, A.S.; writing—review and editing, E.M.M.; visualization, J.R.-C.; supervision, A.G.M.; project administration, G.E.; funding acquisition, G.E. All authors have read and agreed to the published version of the manuscript.

Funding: This research received no external funding.

Institutional Review Board Statement: Not applicable.

Informed Consent Statement: Not applicable.

Data Availability Statement: All data were derived from official statistics released by Eurostat (www.eurostat.eu).

Conflicts of Interest: The authors declare no conflict of interest.

\section{References}

1. Kulu, H.; Boyle, P.J. High fertility in city suburbs: Compositional or contextual effects? Eur. J. Popul. 2009, 25, 157-174. [CrossRef]

2. Kulu, H.; Boyle, P.; Andersson, G. High suburban fertility: Evidence from four northern European countries. Demogr. Res. 2009, 21,915-944. [CrossRef]

3. Criekingen, M.V. Gentrifying the re-urbanisation debatex, not vice versa: The uneven socio-spatial implications of changing transitions to adulthood in Brussels. Popul. Space Place 2010, 16, 381-394. [CrossRef]

4. Lesthaeghe, R. The unfolding story of the second demographic transition. Popul. Dev. Rev. 2010, 36, 211-251. [CrossRef] [PubMed]

5. Haase, A.; Kabisch, S.; Steinführer, A.; Bouzarovski, S.; Hall, R.; Ogden, P. Emergent spaces of reurbanisation: Exploring the demographic dimension of inner-city residential change in a European setting. Popul. Space Place 2010, 16, 443-463. [CrossRef]

6. Nimwegen, N.V. Population change in Europe: Turning challenges into opportunities. Genus 2013, 69, $103-125$.

7. Coleman, D. Europe's demographic future: Determinants, dimensions, and challenges. Popul. Dev. Rev. 2006, 32, 52-95. [CrossRef]

8. Lee, R. The demographic transition: Three centuries of fundamental change. J. Econ. Perspect. 2003, 17, 167-190. [CrossRef]

9. Coleman, D.A. New Europe, new diversity. Popul. Stud. 2008, 62, 113-120. [CrossRef]

10. Harbison, S.F.; Robinson, W.C. Policy Implications of the next world demographic transition. Stud. Fam. Plan. 2002, 33, 37-48. [CrossRef] [PubMed]

11. Lee, R.D.; Reher, D.S. Introduction: The Landscape of demographic transition and its aftermath. Popul. Dev. Rev. 2011, 37, 1-7. [CrossRef]

12. Lesthaeghe, R.J.; Neidert, L. The second demographic transition in the United States: Exception or textbook example? Popul. Dev. Rev. 2006, 32, 669-698. [CrossRef]

13. Reher, D.S. Economic and social implications of the demographic transition. Popul. Dev. Rev. 2011, 37, 11-33. [CrossRef]

14. Sharlin, A. Chapter 5. Urban-Rural differences in fertility in Europe. In The Decline of Fertility in Europe; Princeton University Press: Princeton, NJ, USA, 1986; ISBN 978-1-4008-8669-2.

15. Surkyn, J.; Lesthaeghe, R. Value orientations and the Second Demographic Transition (SDT) in Northern, Western and Southern Europe: An update. Demogr. Res. 2004, S3, 45-86. [CrossRef]

16. Salvati, L.; Ferrara, A.; Chelli, F. Long-term growth and metropolitan spatial structures: An analysis of factors influencing urban patch size under different economic cycles. Geogr. Tidsskr. Dan. J. Geogr. 2018, 118, 56-71. [CrossRef]

17. van de Kaa, D.J. Postmodern fertility preferences: From changing value orientation to new behavior. Popul. Dev. Rev. 2001, 27, 290-331.

18. Kreyenfeld, M.; Andersson, G.; Pailhé, A. Economic uncertainty and family dynamics in Europe: Introduction. Demogr. Res. 2012, S12, 835-852. [CrossRef]

19. Billari, F.C.; Kohler, H.-P. Patterns of Low and lowest-low fertility in Europe. Popul. Stud. 2004, 58, 161-176. [CrossRef]

20. Kertzer, D.I.; White, M.J.; Bernardi, L.; Gabrielli, G. Italy's path to very low fertility: The adequacy of economic and second demographic transition theories. Eur. J. Popul. 2009, 25, 89-115. [CrossRef] 
21. Rontos, K. Demographic trends, young people's attitudes towards marriage and socio-economic changes related to family formation in Greece and in the European Union: A comparative analysis based on official and survey research data. Int. J. Econ. Bus. Adm. (IJEBA) 2015, 3, 11-33. [CrossRef]

22. Goldstein, J.; Kreyenfeld, M.; Jasilioniene, A.; Karaman Örsal, D.D. Fertility reactions to the "Great Recession" in Europe: Recent evidence from order-specific data. Demogr. Res. 2013, 29, 85-104. [CrossRef]

23. Kohler, H.-P.; Billari, F.C.; Ortega, J.A. The emergence of lowest-low fertility in Europe during the 1990s. Popul. Dev. Rev. 2002, 28, 641-680. [CrossRef]

24. Vikat, A. Women's labor force attachment and childbearing in Finland. DemRes 2004, 3, 177-212. [CrossRef]

25. Andersson, G. The Impact of labour-force participation on childbearing behaviour: Pro-cyclical fertility in sweden during the 1980s and the 1990s. Eur. J. Popul. 2000, 16, 293-333. [CrossRef]

26. Engelhardt, H.; Kögel, T.; Prskawetz, A. Fertility and women's employment reconsidered: A macro-level time-series analysis for developed countries, 1960-2000. Popul. Stud. 2004, 58, 109-120. [CrossRef]

27. Hoem, J.M.; Neyer, G.; Andersson, G. Education and childlessness: The relationship between educational field, educational level, and childlessness among Swedish women born in 1955-59. Demogr. Res. 2006, 14, 331-380. [CrossRef]

28. Hoem, J.M.; Neyer, G.; Andersson, G. Educational attainment and ultimate fertility among Swedish women born in 1955-59. Demogr. Res. 2006, 14, 381-404. [CrossRef]

29. Blue, L.; Espenshade, T.J. Population momentum across the demographic transition. Popul. Dev. Rev. 2011, 37, 721-747. [CrossRef] [PubMed]

30. Howell, F.M.; Porter, J.R.; Matthews, S.A. (Eds.) Recapturing space: New middle-range theory in spatial demography. In Spatial Demography Book Series; Springer International Publishing: Berlin/Heidelberg, Germany, 2016; ISBN 978-3-319-22809-9.

31. Kurek, S.; Wójtowicz, M.; Gałka, J. The changing role of migration and natural increase in suburban population growth: The case of a non-capital post-socialist city (The Krakow Metropolitan Area, Poland). Morav. Geogr. Rep. 2015, 23, 59-70. [CrossRef]

32. Kabisch, N.; Haase, D.; Haase, A. Urban population development in Europe, 1991-2008: The examples of Poland and the UK. Int. J. Urban Reg. Res. 2012, 36, 1326-1348. [CrossRef]

33. Boyle, P. Population geography: Does geography matter in fertility research? Prog. Hum. Geogr. 2016. [CrossRef]

34. Walford, N.; Kurek, S. Outworking of the second demographic transition: National trends and regional patterns of fertility change in Poland, and England and Wales, 2002-2012. Popul. Space Place 2016, 22, 508-525. [CrossRef]

35. Chorianopoulos, I.; Pagonis, T.; Koukoulas, S.; Drymoniti, S. Planning, competitiveness and sprawl in the Mediterranean city: The case of Athens. Cities 2010, 27, 249-259. [CrossRef]

36. Chorianopoulos, I.; Tsilimigkas, G.; Koukoulas, S.; Balatsos, T. The shift to competitiveness and a new phase of sprawl in the Mediterranean city: Enterprises guiding growth in Messoghia-Athens. Cities 2014, 39, 133-143. [CrossRef]

37. Kulu, H.; Vikat, A.; Andersson, G. Settlement size and fertility in the Nordic countries. MPIDR Work. Pap. 2006, $24,36$.

38. Hank, K. Regional fertility differences in western Germany: An overview of the literature and recent descriptive findings. Int. J. Popul. Geogr. 2001, 7, 243-257. [CrossRef]

39. Hank, K. Regional social contexts and individual fertility decisions: A multilevel analysis of first and second births in Western Germany. Eur. J. Popul. 2002, 18, 281-299. [CrossRef]

40. Caltabiano, M. Has the fertility decline come to an end in the different regions of Italy? New insights from a cohort approach. Population 2008, 63, 157-171. [CrossRef]

41. Kulu, H. Why do fertility levels vary between urban and rural areas? Reg. Stud. 2013, 47, 895-912. [CrossRef]

42. Glusker, A.I.; Dobie, S.A.; Madigan, D.; Rosenblatt, R.A.; Larson, E.H. Differences in fertility patterns between urban and rural women in Washington State, 1983-1984 to 1993-1994. Women Health 2000, 31, 55-70. [CrossRef] [PubMed]

43. Burcin, B.; Kučera, T. Changes in Fertility and Mortality in the Czech Republic: An Attempt of Regional Demographic Analysis. In New Demographic Faces of Europe: The Changing Population Dynamics in Countries of Central and Eastern Europe; Kučera, T., Kučerová, O.V., Opara, O.B., Schaich, E., Eds.; Springer: Berlin/Heidelberg, Germany, 2000; pp. 371-417, ISBN 978-3-642-59800-5.

44. Vobecká, J.; Piguet, V. Fertility, natural growth, and migration in the Czech Republic: An urban-suburban-rural gradient analysis of long-term trends and recent reversals. Popul. Space Place 2012, 18, 225-240. [CrossRef]

45. Philipov, D.; Kohler, H.-P. Tempo effects in the fertility decline in Eastern Europe: Evidence from Bulgaria, the Czech Republic, Hungary, Poland, and Russia. Eur. J. Popul. 2001, 17, 37-60. [CrossRef]

46. Kulu, H. Migration and fertility: Competing hypotheses re-examined. Eur. J. Popul. 2005, 21, 51-87. [CrossRef]

47. Kulu, H. Fertility of internal migrants: Comparison between Austria and Poland. Popul. Space Place 2006, 12, 147-170. [CrossRef]

48. Thygesen, L.C.; Knudsen, L.B.; Keiding, N. Modelling regional variation of first-time births in Denmark 1980-1994 by an age-period-cohort model. Demogr. Res. 2005, 13, 573-596. [CrossRef]

49. Boyle, P.J.; Graham, E.; Feng, Z. Contextualising Demography: The Significance of Local Clusters of Fertility in Scotland; Max Planck Institute for Demographic Research: Rostock, Germany, 2007; p. WP-2007-036.

50. Mulder, C.H.; Wagner, M. The connections between family formation and first-time home ownership in the context of West Germany and the Netherlands. Eur. J. Popul. 2001, 17, 137-164. [CrossRef]

51. De Beer, J.; Deerenberg, I. An explanatory model for projecting regional fertility differences in the Netherlands. Popul. Res. Policy Rev. 2007, 26, 511-528. [CrossRef] 
52. Michielin, F. Lowest low fertility in an urban context: The role of migration in Turin, Italy. Popul. Space Place 2004, $10,331-347$. [CrossRef]

53. Sobotka, T. Tempo-quantum and period-cohort interplay in fertility changes in Europe: Evidence from the Czech Republic, Italy, the Netherlands and Sweden. Demogr. Res. 2003, 8, 151-214. [CrossRef]

54. Sobotka, T.; Winkler-Dworak, M.; Testa, M.R.; Lutz, W.; Philipov, D.; Engelhardt, H.; Gisser, R. Monthly estimates of the quantum of fertility: Towards a fertility monitoring system in Austria. Vienna Yearb. Popul. Res. 2005, 3, 109-141.

55. Balbo, N.; Billari, F.C.; Mills, M. Fertility in advanced societies: A review of research. Eur. J. Popul. 2013, 29, 1-38. [CrossRef]

56. Kulu, H.; Vikat, A. Fertility differences by housing type: The effect of housing conditions or of selective moves? Demogr. Res. 2007, S6, 775-802. [CrossRef]

57. Caldwell, J.C.; Schindlmayr, T. Explanations of the fertility crisis in modern societies: A search for commonalities. Popul. Stud. 2003, 57, 241-263. [CrossRef]

58. Liu, L. Fertility trends in China's more developed urban districts: The case of four cities. Popul. Space Place 2005, 11, 411-424. [CrossRef]

59. Salvati, L. Towards a polycentric region? The socio-economic trajectory of Rome, an 'Eternally Mediterraneanx City. Tijdschr. Voor Econ. Soc. Geogr. 2014, 105, 268-284. [CrossRef]

60. De Rosa, S.; Salvati, L. Beyond a 'side street story'? Naples from spontaneous centrality to entropic polycentricism, towards a 'crisis city'. Cities 2016, 51, 74-83. [CrossRef]

61. Kalmijn, M.; van Tubergen, F. Ethnic intermarriage in the Netherlands: Confirmations and refutations of accepted insights. Eur. J. Popul. 2006, 22, 371-397. [CrossRef]

62. Sobotka, T.; Toulemon, L. Overview chapter 4: Changing family and partnership behaviour: Common trends and persistent diversity across Europe. Demogr. Res. 2008, S7, 85-138. [CrossRef]

63. Goldstein, J.R.; Sobotka, T.; Jasilioniene, A. The end of “lowest-low” fertility? Popul. Dev. Rev. 2009, 35, 663-699. [CrossRef]

64. Rontos, K. Prospects for a new family formation and for its impact on fertility: Some research evidences from Greece. Stat. Rev. 2007, 3, 49-67.

65. Chelli, F.; Rosti, L. Age and gender differences in Italian workers' mobility. Int. J. Manpow. 2002, 23, 313-325. [CrossRef]

66. Rosti, L.; Chelli, F. Self-employment among Italian female graduates. Educ. Train. 2009, 51, 526-540. [CrossRef]

67. Rosti, L.; Chelli, F. Higher education in non-standard wage contracts. Educ. Train. 2012, 54, 142-151. [CrossRef]

68. Kulu, H.; Steele, F. Interrelationships between childbearing and housing transitions in the family life course. Demography 2013, 50, 1687-1714. [CrossRef] [PubMed]

69. McQuillan, K. When does religion influence fertility? Popul. Dev. Rev. 2004, 30, 25-56. [CrossRef]

70. Hoem, J.M. Why does Sweden have such high fertility? Demogr. Res. 2005, 13, 559-572. [CrossRef]

71. Andersson, G.; Rønsen, M.; Knudsen, L.B.; Lappegård, T.; Neyer, G.; Skrede, K.; Teschner, K.; Vikat, A. Cohort fertility patterns in the Nordic countries. Demogr. Res. 2009, 20, 313-352. [CrossRef]

72. Kulu, H.; Washbrook, E. Residential context, migration and fertility in a modern urban society. Adv. Life Course Res. 2014, 21, 168-182. [CrossRef]

73. Zeitler, E.; Buys, L. Mobility and out-of-home activities of older people living in suburban environments: 'Because I'm a driver, I don't have a problem'. Ageing Soc. 2015, 35, 785-808. [CrossRef]

74. Lee, J.; Hong, S.; Park, Y. Predictable surprise: The spatial and social morphology of aging suburbs in the U.S. metropolitan areas. Sustainability 2017, 9, 458. [CrossRef]

75. Kohler, H.-P.; Ortega, J.A. Tempo-adjusted period parity progression measures: Assessing the implications of delayed childbearing for cohort fertility in Sweden, the Netherlands and Spain. Demogr. Res. 2002, 6, 145-190. [CrossRef]

76. Domingo, A.; Gil-Alonso, F.; Robertson, G. Immigration and changing labour force structure in the Southern European Union. Population 2007, 62, 709-727. [CrossRef]

77. Champion, A.G. A changing demographic regime and evolving poly centric urban regions: Consequences for the size, composition and distribution of city populations. Urban Stud. 2001, 38, 657-677. [CrossRef]

78. Bayona-Carrasco, J.; Alonso, F.G.; Rúbies, I.P. Dinàmica residencial de la població estrangera a les principals regions metropolitanes d'Espanya. Rev. Catalana Sociol. 2011, 15-32. [CrossRef]

79. Bayona, J.; López Gay, A. Concentración, segregación y movilidad residencial de los extranjeros en Barcelona. Geogràfica 2011, 57, 381. [CrossRef]

80. Buzar, S.; Ogden, P.; Hall, R.; Haase, A.; Kabisch, S.; Steinfiihrer, A. Splintering urban populations: Emergent landscapes of reurbanisation in four European cities. Urban Stud. 2007, 44, 651-677. [CrossRef]

81. Gil-Alonso, F.; Bayona-i-Carrasco, J.; Pujadas-i-Rúbies, I. From boom to crash: Spanish urban areas in a decade of change (2001-2011). Eur. Urban Reg. Stud. 2016, 23, 198-216. [CrossRef]

82. Milewski, N. First child of immigrant workers and their descendants in West Germany: Interrelation of events, disruption, or adaptation? Demogr. Res. 2007, 6, 859-896. [CrossRef]

83. Gigliarano, C.; Chelli, F.M. Measuring inter-temporal intragenerational mobility: An application to the Italian labour market. Qual Quant. 2016, 50, 89-102. [CrossRef]

84. Chelli, F.M.; Ciommi, M.; Emili, A.; Gigliarano, C.; Taralli, S. Assessing the equitable and sustainable well-being of the Italian provinces. Int. J. Unc. Fuzz. Knowl. Based Syst. 2016, 24, 39-62. [CrossRef] 
85. Ciommi, M.; Gentili, A.; Ermini, B.; Gigliarano, C.; Chelli, F.M.; Gallegati, M. Have your cake and eat it too: The well-being of the Italians (1861-2011). Soc. Indic. Res. 2017, 134, 473-509. [CrossRef]

86. Lutz, W.; Qiang, R. Determinants of human population growth. Philos. Trans. R. Soc. Lond. B Biol. Sci. 2002, 357, 1197-1210. [CrossRef] [PubMed]

87. Carlucci, M.; Chelli, F.M.; Salvati, L. Toward a new cycle: Short-term population dynamics, gentrification, and re-urbanization of Milan (Italy). Sustainability 2018, 10, 3014. [CrossRef]

88. Salvati, L.; Carlucci, M. Land-use structure, urban growth, and periurban landscape: A multivariate classification of the European cities. Environ. Plan. B Plan. Des. 2015, 42, 801-829. [CrossRef]

89. Ogden, P.E.; Hall, R. Households, reurbanisation and the rise of living alone in the principal French cities, 1975-1990. Urban Stud. 2000, 37, 367-390. [CrossRef]

90. Lee, K.O.; Painter, G. What happens to household formation in a recession? J. Urban Econ. 2013, 76, 93-109. [CrossRef]

91. Marek, K.D.; Rantz, M.J. Aging in place: A new model for long-term care. Nurs. Adm. Q. 2000, 24, 1-11. [CrossRef]

92. Andrew, M.K.; Mitnitski, A.B.; Rockwood, K. Social vulnerability, frailty and mortality in elderly people. PLoS ONE 2008, 3, e2232. [CrossRef]

93. Andrew, M.K.; Mitnitski, A.; Kirkland, S.A.; Rockwood, K. The impact of social vulnerability on the survival of the fittest older adults. Age Ageing 2012, 41, 161-165. [CrossRef]

94. Lucy, W.H.; Phillips, D.L. Suburban decline: The next urban crisis. Issues Sci. Technol. 2000, 17, 55-62.

95. Dijkstra, L.; Garcilazo, E.; McCann, P. The effects of the global financial crisis on European regions and cities. J. Econ. Geogr. 2015, 15, 935-949. [CrossRef]

96. Ren, X. City power and urban fiscal crises: The USA, China, and India. Int. J. Urban Sci. 2015, 19, 73-81. [CrossRef]

97. Carbonaro, G.; Leanza, E.; McCann, P.; Medda, F. Demographic decline, population aging, and modern financial approaches to urban policy. Int. Reg. Sci. Rev. 2018, 41, 210-232. [CrossRef]

98. Valkonen, T.; Martikainen, P.; Jalovaara, M.; Koskinen, S.; Martelin, T.; Mäkelä, P. Changes in socioeconomic inequalities in mortality during an economic boom and recession among middle-aged men and women in Finland. Eur. J. Public Health 2000, 10, 274-280. [CrossRef]

99. Sobotka, T.; Skirbekk, V.; Philipov, D. Economic recession and fertility in the developed world. Popul. Dev. Rev. 2011, 37, 267-306. [CrossRef] [PubMed]

100. Chelli, F.; Gigliarano, C.; Mattioli, E. The impact of inflation on heterogeneous groups of households: An application to Italy. Econ. Bull. 2009, 29, 1276-1295.

101. Pérez, J.M.G. The real estate and economic crisis: An opportunity for urban return and rehabilitation policies in Spain. Sustainability 2010, 2, 1571-1601. [CrossRef]

102. Simou, E.; Koutsogeorgou, E. Effects of the economic crisis on health and healthcare in Greece in the literature from 2009 to 2013: A systematic review. Health Policy 2014, 115, 111-119. [CrossRef]

103. Carlucci, M.; Grigoriadis, E.; Rontos, K.; Salvati, L. Revisiting a hegemonic concept: Long-term 'Mediterranean Urbanization' in between city re-polarization and metropolitan decline. Appl. Spat. Anal. 2017, 10, 347-362. [CrossRef]

104. Kroll, F.; Kabisch, N. The relation of diverging urban growth processes and demographic change along an urban-rural gradient. Popul. Space Place 2012, 18, 260-276. [CrossRef]

105. Rodríguez-Moya, J.M.; Pozo-Rivera, E. Diferencias socioespaciales en la fecundidad madrileña en el cambio de siglo. Estud. Geográficos 2003, 64, 455-486.

106. Villanueva, C.L.; Rúbies, I.P.; Carrasco, J.B. i Households within the residential mobility process: The case of the Barcelona metropolitan region. Arch. Studi Urbani Reg. 2013, 1, 57-81.

107. Kabisch, N.; Haase, D. Diversifying European agglomerations: Evidence of urban population trends for the 21st century. Popul. Space Place 2011, 17, 236-253. [CrossRef]

108. Salvati, L.; Ciommi, M.T.; Serra, P.; Chelli, F.M. Exploring the spatial structure of housing prices under economic expansion and stagnation: The role of socio-demographic factors in metropolitan Rome, Italy. Land Use Policy 2019, 81, 143-152. [CrossRef]

109. Johnson, K.M.; Voss, P.R.; Hammer, R.B.; Fuguitt, G.V.; Mcniven, S. Temporal and spatial variation in age-specific net migration in the United States. Demography 2005, 42, 791-812. [CrossRef]

110. Bavel, J.V.; Reher, D.S. The baby boom and its causes: What we know and what we need to know. Popul. Dev. Rev. 2013, 39, 257-288. [CrossRef]

111. Taulbut, M.; Robinson, M. The chance to work in Britain: Matching unemployed people to vacancies in good times and bad. Reg. Stud. 2015, 49, 2070-2086. [CrossRef]

112. Sayas, J.P. Urban sprawl in the periurban coastal zones of Athens. GRSR 2016, 121, 71. [CrossRef]

113. Kasimis, C. Survival and expansion: Migrants in Greek rural regions. Popul. Space Place 2008, 14, 511-524. [CrossRef]

114. Morelli, V.G.; Rontos, K.; Salvati, L. Between suburbanisation and re-urbanisation: Revisiting the urban life cycle in a Mediterranean compact city. Urban. Res. Pract. 2014, 7, 74-88. [CrossRef]

115. Rontos, K.; Grigoriadis, E.; Sateriano, A.; Syrmali, M.; Vavouras, I.; Salvati, L. Lost in protest, found in segregation: Divided cities in the light of the 2015 "Oxı" referendum in Greece. City Cult. Soc. 2016, 7, 139-148. [CrossRef]

116. Alonso, F.G.; Carrasco, J.B.; Villanueva, C.L.; Rúbies, I.P. Diferencias geográficas de la fecundidad en España: Una perspectiva provincial. Pap. Geogr. 2017, 21-38. [CrossRef] 
117. Moos, M. “Generationed” space: Societal restructuring and young adults' changing residential location patterns. Can. Geogr. Géographe Can. 2014, 58, 11-33. [CrossRef]

118. Moos, M. From gentrification to youthification? The increasing importance of young age in delineating high-density living. Urban. Stud. 2016, 53, 2903-2920. [CrossRef]

119. Moos, M.; Mendez, P. Suburban ways of living and the geography of income: How homeownership, single-family dwellings and automobile use define the metropolitan social space. Urban Stud. 2015, 52, 1864-1882. [CrossRef]

120. Moore, E.; Skaburskis, A. Canada's increasing housing affordability burdens. Hous. Stud. 2004, 19, 395-413. [CrossRef]

121. Beer, A.; Faulkner, D.; Paris, C.; Clower, T.L. Housing Transitions through the Life Course: Aspirations, Needs and Policy; Illustrated Edition; Policy Press: Bristol, UK; Portland, OR, USA, 2011; ISBN 978-1-84742-428-0.

122. Furlong, H. Young People and Social Change: New Perspectives; Open University Press: Buckingham, UK, 2006; ISBN 978-0-33521868-4.

123. Boudarbat, B.; Lemieux, T.; Riddell, W.C. The Evolution of the returns to human capital in Canada, 1980-2005. Can. Public Policy 2010, 36, 63-89. [CrossRef]

124. Patterson, Z.; Saddier, S.; Rezaei, A.; Manaugh, K. Use of the urban core index to analyze residential mobility: The case of seniors in Canadian metropolitan regions. J. Transp. Geogr. 2014, 41, 116-125. [CrossRef]

125. Munoz, F. Lock living: Urban sprawl in Mediterranean cities. Cities 2003, 20, 381-385. [CrossRef]

126. Serra, P.; Vera, A.; Tulla, A.F.; Salvati, L. Beyond urban-rural dichotomy: Exploring socioeconomic and land-use processes of change in Spain (1991-2011). Appl. Geogr. 2014, 55, 71-81. [CrossRef]

127. Cuadrado-Ciuraneta, S.; Durà-Guimerà, A.; Salvati, L. Not only tourism: Unravelling suburbanization, second-home expansion and "rural" sprawl in Catalonia, Spain. Urban Geogr. 2017, 38, 66-89. [CrossRef]

128. Garcia-López, M.-À.; Muñiz, I. Employment decentralisation: Polycentricity or scatteration? Case Barc. Urban Stud. 2010. [CrossRef]

129. Saurí, D.; del Moral, L. Recent developments in Spanish water policy. Altern. Confl. End Hydraul. Age. Geoforum 2001, 32, 351-362.

130. Vidal, M.; Domene, E.; Sauri, D. Changing geographies of water-related consumption: Residential swimming pools in suburban Barcelona. Area 2011, 43, 67-75. [CrossRef]

131. Di Feliciantonio, C.; Salvati, L. 'Southern' alternatives of urban diffusion: Investigating settlement characteristics and socioeconomic patterns in three Mediterranean regions. Tijdschr. Voor Econ. Soc. Geogr. 2015, 106, 453-470. [CrossRef]

132. Di Feliciantonio, C.; Salvati, L.; Sarantakou, E.; Rontos, K. Class diversification, economic growth and urban sprawl: Evidences from a pre-crisis European city. Qual. Quant. 2018, 52, 1501-1522. [CrossRef]

133. Kazemzadeh-Zow, A.; Zanganeh Shahraki, S.; Salvati, L.; Samani, N.N. A spatial zoning approach to calibrate and validate urban growth models. Int. J. Geogr. Inf. Sci. 2017, 31, 763-782. [CrossRef]

134. Duvernoy, I.; Zambon, I.; Sateriano, A.; Salvati, L. Pictures from the other side of the fringe: Urban growth and peri-urban agriculture in a post-industrial city (Toulouse, France). J. Rural Stud. 2018, 57, 25-35. [CrossRef]

135. Salvati, L.; Zambon, I.; Chelli, F.M.; Serra, P. Do spatial patterns of urbanization and land consumption reflect different socioeconomic contexts in Europe? Sci. Total. Environ. 2018, 625, 722-730. [CrossRef]

136. Zambon, I.; Serra, P.; Sauri, D.; Carlucci, M.; Salvati, L. Beyond the 'Mediterranean city': Socioeconomic disparities and urban sprawl in three Southern European cities. Geogr. Ann. Ser. B Hum. Geogr. 2017, 99, 319-337. [CrossRef]

137. Zambon, I.; Benedetti, A.; Ferrara, C.; Salvati, L. Soil matters? A multivariate analysis of socioeconomic constraints to urban expansion in Mediterranean Europe. Ecol. Econ. 2018, 146, 173-183. [CrossRef] 